\title{
PROSEDUR-PROSEDUR UNTUK MENDAPATKAN HAK PATEN
}

\author{
Niko saputra \\ 155100054 \\ Fakultas Komputer, 448757190 \\ nikosaputra.student@umitra.ac.id
}

\begin{abstract}
Hak paten adalah perbuatan yang merupakan hak eksklusif dari pemegang paten, yaitu mengenai penjualan, penggunaan dan halhal lain yang berkaitan dengan objek yang telah dipatenkan3. Dalam proses perolehan paten memiliki langkah, dan juga syarat didalamnya, yang harus dipenuhi untuk dapat mematenkan suatu invensi. Adapun syarat terhadap invensi yang dapat diberi paten adalah : invensi baru, jika invensi yang diajukan paten tersebut tidak sama dengan teknologi yang diungkap sebelumnya serta Invensi mengandung langkah inovatif, jika invensi tersebut merupakan hal yang tidak diduga sebelumnya bagi seseorang yang mempunyai keahlian tertentu dibidang teknik, invensi tersebut dapat diterapkan dalam industri, artinya invensi yang dapat dipatenkan adalah invensi yang dapat digunakan di bidang industry, dan mengandung langkah inventif (kebaharuan) dan Untuk mematenkan sebuah produk itu tidak lah gampang harus melaluli prosedur-prosedur yang sudah ditetapkan.
\end{abstract}

Kata Kunci : prosedur pembuatan hak paten

\section{A. INTRODUCTION}

\section{Definisi paten}

Paten adalah hak eksklusif inventor atas invensi di bidang teknologi untuk selama waktu tertentu melaksanakan sendiri atau memberikan persetujuan kepada pihak lain untuk melaksanakan invensinya

\section{2.invensi}

Invensi adalah ide inventor yang dituangkan ke dalam suatu kegiatan pemecahan masalah yang spesifik di bidang teknologi, dapat berupa produk atau proses atau penyempurnaan dan pengembangan produk atau proses. 


\section{Invensi yang dapat dipatenkan}

Invensi dapat dipatenkan jika invensi tersebut:

- Jika pada saat pengajuan permohonan Paten invensi tersebut tidak sama dengan teknologi yang diungkapkan sebelumnya;

- Mengandung langkah inventif.

Jika invensi tersebut merupakan hal yang tidak dapat diduga sebelumnya bagi seseorang yang mempunyai keahlian tertentu di bidang teknik;

- Dapat diterapkan dalam industri.

Jika invensi tersebut dapat diproduksi atau dapat digunakan dalam berbagai jenis industri.

\section{Berapa lama Paten berlaku?}

- Paten diberikan untuk jangka waktu selama 20 tahun sejak tanggal penerimaan permohonan Paten.
-Paten sederhana diberikan untuk jangka waktu 10 tahun sejak tanggal penerimaan permohonan Paten sederhana.

\section{Bagaimana cara mengajukan permohonan Paten?}

1. Mengajukan permohonan ke kantor Direktorat Jenderal Kekayaan Intelektual (DJKI) secara tertulis dalam Bahasa Indonesia dengan mengisi formulir permohonan yang disediakan dan diketik rangkap

2. Pemohon wajib melampirkan:

a. surat kuasa khusus, apabila permohonan diajukan melalui konsultan KI terdaftar selaku kuasa;

b. surat pengalihan hak, apabila permohonan diajukan oleh pihak lain yang bukan inventor

c. deskripsi permohonan Paten dibuat rangkap 2 dan mencakup:

- judul invensi, dibuat dalam huruf kapital dan tidak digaris bawah; 
- bidang teknik invensi,

memuat secara umum

dimana invensi ini

termasuk di dalam bidang

teknik tersebut dengan

mengemukakan

kekhususannya;

- latar belakang invensi,

harus dikemukakan

teknologi yang telah ada

sebelumnya dan relevan

dengan invensi tersebut;

- ringkasan invensi,

memuat ciri teknis dari

pokok invensi yang

diungkapkan dalam

klaim;

- uraian singkat gambar

(bila disertakan gambar),

memuat keterangan

gambar secara singkat;

- uraian lengkap invensi,

merupakan suatu

pengungkapan invensi

yang selengkap- lengkapnya, tidak boleh

ada yang tertinggal atau

tidak diungkapkan;

- klaim (dibuat pada

halaman terpisah),

memuat pokok invensi

dan tidak boleh berisikan

gambar atau grafik tetapi

dapat memuat tabel rumus

matematika atau reaksi

kimia;

- abstrak (dibuat pada

halaman terpisah), berisi

ringkasan dari uraian

lengkap invensi dan tidak

lebih dari 200 kata.

- gambar, apabila ada dibuat

rangkap 2: hanya memuat tanda-

tanda, simbol, huruf, angka,

bagan, atau diagram yang

menjelaskan tentang bagian-

bagian dari invensi, tetapi tidak

boleh terdapat kata-kata

penjelasan; 
○ bukti prioritas asli, dan

terjemahan halaman depan dalam

bahasa Indonesia rangkap 2,

apabila diajukan dengan hak

prioritas;

○ terjemahan uraian invensi dalam

bahasa Inggris, apabila invensi

tersebut aslinya dalam bahasa

asing selain bahasa Inggris;

○ bukti pembayaran biaya

permohonan Paten;

3. deskripsi, klaim, abstrak dan

gambar sebagaimana dimaksud

dalam butir 2 huruf $\mathrm{c}$ dan d

ditentukan sebagai berikut:

4. setiap lembar kertas hanya salah

satu mukanya yang boleh

dipergunakan untuk penulisan

dan gambar;

5. deskripsi, klaim dan abstrak

diketik dalam kertas HVS atau

yang sejenis dan terpisah, ukuran

A4, berat minimum 80 gram

dengan batas sebagai berikut:

○ batas atas: $2 \mathrm{~cm}$
○ batas bawah: $2 \mathrm{~cm}$

○ batas kiri: $2,5 \mathrm{~cm}$

○ batas kanan: $2 \mathrm{~cm}$

6. kertas A4 tersebut harus

berwarna putih, rata tidak

mengkilap dan pemakaiannya

dilakukan dengan menempatkan

sisinya yang pendek di bagian

atas dan bawah (kecuali

dipergunakan untuk gambar);

7. setiap lembar deskripsi, klaim

dan gambar diberi nomor urut

angka Arab pada bagian tengah

atas dan tidak pada batas

sebagaimana yang dimaksud

pada butir 3 huruf b (1);

8. pada setiap lima baris pengetikan

baris uraian dan klaim, harus

diberi nomor baris dan setiap

halaman baru merupakan

permulaan (awal) nomor dan

ditempatkan di sebelah kiri uraian

atau klaim serta tidak pada batas

sebagaimana yang dimaksud

pada butir 3 huruf b (3); 
9. pengetikan harus dilakukan dengan menggunakan tinta

(toner) warna hitam, dengan

ukuran spasi 1,5 dan huruf tegak

berukuran tinggi huruf minimum

$0,21 \mathrm{~cm}$;

10. tanda-tanda dengan garis, rumus

kimia, dan tanda-tanda tertentu

dapat ditulis dengan tangan;

11. gambar harus menggunakan tinta

cina hitam pada kertas gambar

putih ukuran A4 dengan berat

minimum 100 gram yang tidak

mengkilap dengan batas sebagai

berikut:

○ batas atas: $2,5 \mathrm{~cm}$

○ batas bawah: $1 \mathrm{~cm}$

○ batas kiri: $2,5 \mathrm{~cm}$

○ batas kanan: $1,5 \mathrm{~cm}$

12. seluruh dokumen Paten yang

diajukan harus dalam lembar-

lembar kertas utuh, tidak boleh

dalam keadaan tersobek, terlipat, rusak atau gambar yang

ditempelkan;

13. setiap istilah yang dipergunakan

dalam deskripsi, klaim, abstrak

dan gambar harus konsisten satu

sama lain.

\section{B. CONCLUSION}

1. Hak paten adalah hak khusus yang diberi seseorang atau permohonannya kepada orang itu yang menciptakan produk baru.

2. Secara umum ada beberapa prosedur untuk mendapatkan hak paten :

Surat pernyataan hak,Surat perngalihan hak,Surat kuasa,

Fotocopi KTP/identigas pemohon,

Fotokopi Akta pendirian badan hukum yang dilegaliris, Fotokopi NPWP badan hukum,

Fotokopi KTP atas nama pemohon badan hukum untuk ditandatangai surat pernyataan dan surat kuasa,

3. Pemberlakuan hak paten dan jangka waktu nya : Paten diberikan untuk jangka waktu selama 20 tahun sejak tanggal 
penerimaan permohonan

Paten,Paten sederhana

diberikan untuk jangka

waktu 10 tahun sejak

tanggal penerimaan

permohonan Paten

sederhana.

4. Invensi adalah ide inventor yang dituangkan ke dalam suatu kegiatan pemecahan masalah yang spesifik di bidang teknologi, dapat berupa produk atau proses atau penyempurnaan dan pengembangan produk atau proses.

5. Jadi untuk mengurus permohonan hak paten itu tidak mudah harus melalui tahapan-tahapan seperti di atas dan jika sudah di patenkan maka produk yang kita buat itu sudah di lindungi oleh badan hukum jika ada yang mengklaim hak paten terhadap produk kita akan terkena pasal yang sudah berlaku.

\section{ACKNOWLEDGEMENT}

University Of Indonesia University Of Mitra Indonesia Telkom University University Of Mellbourne Saitama University

\section{REFERENCE(Based ISO 690 )}

A. S. Putra And O. M. Febriani, "Knowledge Management Online Application In Pdam Lampung Province," In Prosiding International Conference On Information Technology And Business (Icitb), 2018, Pp. 181187.

[2] A. S. Putra, O. M. Febriani, And B. Bachry, "Implementasi Genetic Fuzzy System Untuk Mengidentifikasi Hasil Curian Kendaraan Bermotor Di Polda Lampung," J. Sist. Inf. Dan Manaj. Basis Data, Vol. 1, No. 1, Pp. 21-30, 2018.

[3] O. M. Febriani And A. S. Putra, "Sistem Informasi Monitoring Inventori Barang Pada Balai Riset Standardisasi Industri Bandar Lampung," J. Inform., Vol. 13, No. 1, Pp. 90-98, 2014.

[4] Putra, Arie Setya. "2018 Artikel Struktur Data, Audit Dan Jaringan Komputer." (2018).

[5] Putra, A. S. (2018, July 17). Paperplain Fundamental Create Application With Borland Delphi 7.0 University Of Mitra Indonesia. Retrieved From Osf.Io/Pbrn9.

\section{E. REFERENCE(Based APA )}

Putra, A. S., Aryanti, D. R., \& Hartati, I. (2018, November). Metode SAW (Simple Additive Weighting) sebagai Sistem Pendukung Keputusan Guru Berprestasi (Studi Kasus: SMK Global Surya). In Prosiding Seminar Nasional Darmajaya (Vol. 1, No. 1, pp. 85-97). 
Sari, D. P., Febriani, O. M., \& Putra, A. S. (2018, November). Perancangan Sistem Informasi SDM Berprestasi pada SD Global Surya. In Prosiding Seminar Nasional Darmajaya (Vol. 1, No. 1, pp. 289-294).

Putra, A. S. (2018). Paperplain: Execution Fundamental Create Application With Borland Delphi 7.0 University Of Mitra Indonesia.

Putra, A. S., Sukri, H., \& Zuhri, K. Sistem Monitoring Realtime Jaringan Irigasi Desa (JIDES) Dengan Konsep Jaringan Sensor Nirkabel. IJEIS (Indonesian Journal of Electronics and Instrumentation Systems), 8(2), 221-232.

Darmawan, A., Yuliawati, D., Marcella, O., \& Firmandala, R. (2016). Sistem Absensi dan Pelaporan Berbasis Fingerprint dan SMS Gateway. EXPLORE, 7(1).

Febriani, O. M., Wahyuni, T., \& Yusuf, S. (2017). DESIGN OF WEBSITEBASED INFORMATION SYSTEM FOR EDOCUMENT ADMINISTRASI IN THE COMMUNITY SERVICE UNIT (A Case Study at Rajabasa District). INTERNATIONAL JOURNAL OF COMPUTERS \& TECHNOLOGY, 16(7), 7010-7020.

Febriani, O. M., \& Wahyuni, T. (2017, October). PERANCANGAN SISTEM EDOCUMENT ADMINISTRASI LOGBOOK PENELITIAN PADA UNIT LAYANAN DI BANDAR LAMPUNG. In Prosiding Seminar Nasional Darmajaya (Vol. 1, No. 1, pp. 187-194).
Febriani, O. M., \& Permadi, A. B. (2017). Implementasi Sistem Aplikasi Data Bimbingan dan Pelanggaran Siswa pada Sekolah Menengah Atas di Lampung Tengah dengan Metode Analisis dan Desain Sistem Terdistribusi (SSAD). EXPERT, 7(1).

Febriani, O. M., \& Ambarwati, L. (2015). PERANCANGAN APLIKASI PENGOLAHAN DATA PENJUALAN UKM KELANTING KHAS TELO DESA SIDOHARJO KECAMATAN JATI AGUNG KABUPATEN LAMPUNG SELATAN. Jurnal Teknologi Informasi dan Bisnis Pengabdian Masyarakat Darmajaya, 1(1), 77-95.

Febriani, O. M. (2015). Rancang Bangun Aplikasi E-commercemenggunakan Freewebstore pada UKM Kelanting di Desa Sidoharjo Lampung Selatan. Prosiding Sembistek 2014, 1(02), 446458. 